Alaska Petroleum Systems Project

\title{
Influence of the Kingak Shale Ultimate Shelf Margin on Frontal Structures of the Brooks Range in the National Petroleum Reserve in Alaska
}

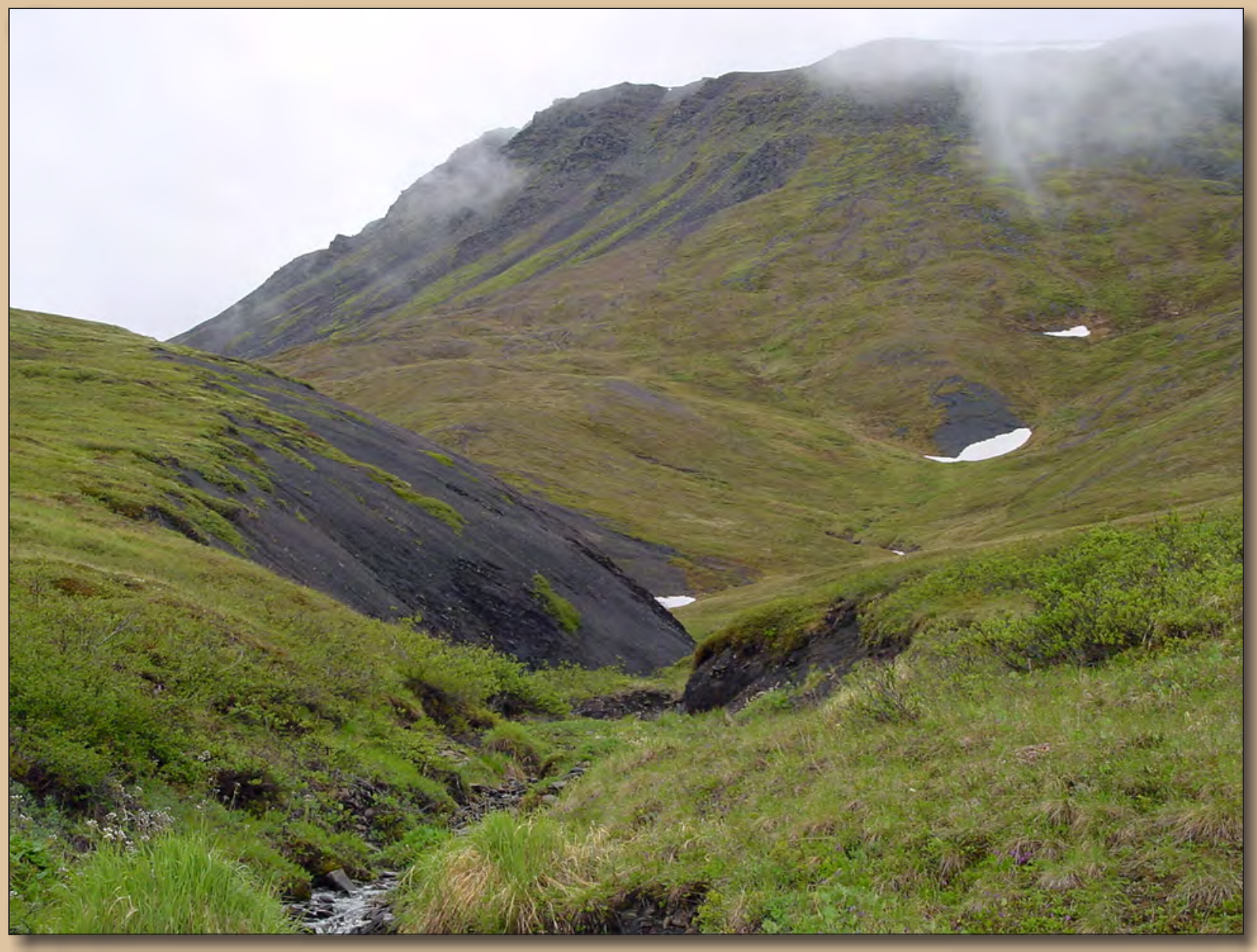

Scientific Investigations Report 2014-5056 
Cover. Exposure of Kingak Shale (foreground and lower ridge) overlain by sandstone in the Torok Formation at ridgetop. Pebble shale unit and gamma ray zone are either covered by talus below the Torok Formation or are absent in this area owing to erosion at base of the Torok Formation. The Torok sandstone at ridgetop comprises basin-floor fan deposits inferred to be part of the Torok foredeep wedge (see fig. 2 and text). Exposure is on Gilead syncline, approximately 150 kilometers east of the Colville and East Umiat well locations shown in figure 3. Relief from foreground exposure to top of ridge is approximately 300 meters. 


\section{Influence of the Kingak Shale Ultimate Shelf Margin on Frontal Structures of the Brooks Range in the National Petroleum Reserve in Alaska}

By Natalie E. Stier, Christopher D. Connors, and David W. Houseknecht

Alaska Petroleum Systems Project

Scientific Investigations Report 2014-5056 


\title{
U.S. Department of the Interior SALLY JEWELL, Secretary
}

\section{U.S. Geological Survey Suzette M. Kimball, Acting Director}

\author{
U.S. Geological Survey, Reston, Virginia: 2014
}

For more information on the USGS - the Federal source for science about the Earth, its natural and living resources, natural hazards, and the environment, visit http://www.usgs.gov or call 1-888-ASK-USGS.

For an overview of USGS information products, including maps, imagery, and publications, visit http://www.usgs.gov/pubprod

To order this and other USGS information products, visit http://store.usgs.gov

Any use of trade, firm, or product names is for descriptive purposes only and does not imply endorsement by the U.S. Government.

Although this information product, for the most part, is in the public domain, it also may contain copyrighted materials as noted in the text. Permission to reproduce copyrighted items must be secured from the copyright owner.

Suggested citation:

Stier, N.E., Connors, C.D., and Houseknecht, D.W., 2014, Influence of the Kingak Shale ultimate shelf margin on frontal structures of the Brooks Range in the National Petroleum Reserve in Alaska: U.S. Geological Survey Scientific Investigations Report 2014-5056, 11 p., 1 pl., http://dx.doi.org/10.3133/sir20145056.

ISSN 2328-0328 (online) 


\section{Contents}

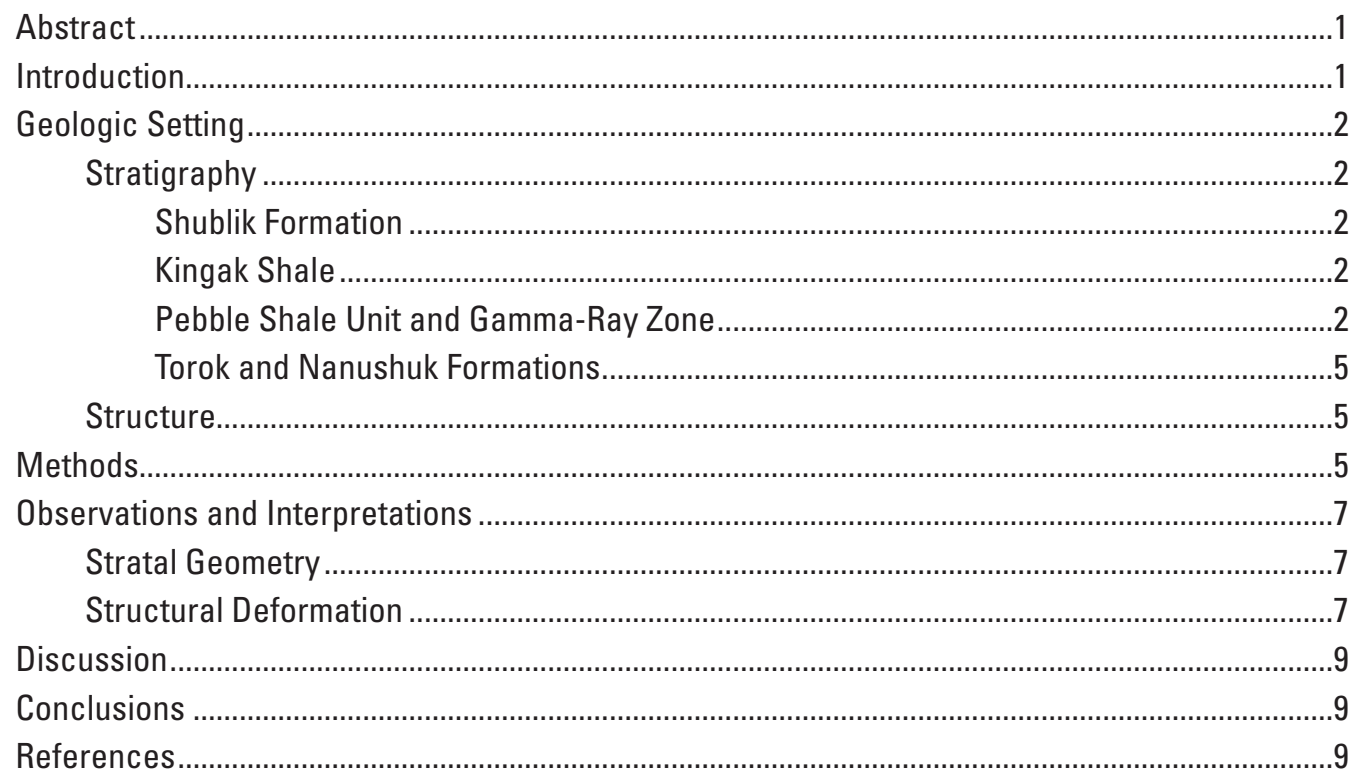

\section{Figures}

1. Chronostratigraphy of the National Petroleum Reserve in Alaska showing tectonostratigraphic sequences.

2. Cross section showing architectural elements of the Shublik through Nanushuk Formations showing the opposing wedges formed by deposition of the Torok Formation on the south-facing, relict shelf-margin geometry of the Kingak Shale...........4

3. Map showing digital elevation model of the National Petroleum Reserve in Alaska showing regional structural features mapped at surface, exploration well locations, and USGS regional seismic lines...

4. Isochron map of the stratigraphic interval between the top of the Kingak Shale and the top of the Shublik Formation. .8

\section{Plate}

[Available online at http://pubs.usgs.gov/sir/2014/5056/]

1. Interpreted seismic lines in southwestern National Petroleum Reserve in Alaska showing structures associated with the Carbon Creek fault zone and the Kingak Shale ultimate shelf margin. 


\section{Conversion Factors}

SI to Inch/Pound

\begin{tabular}{lll}
\hline \multicolumn{1}{c}{ Multiply } & \multicolumn{1}{c}{ By } & \multicolumn{1}{c}{ To obtain } \\
\hline & Length & \\
\hline meter $(\mathrm{m})$ & 3.281 & foot $(\mathrm{ft})$ \\
kilometer $(\mathrm{km})$ & 0.6214 & mile (mi) \\
\hline
\end{tabular}




\title{
Influence of the Kingak Shale Ultimate Shelf Margin on Frontal Structures of the Brooks Range in the National Petroleum Reserve in Alaska
}

\author{
By Natalie E. Stier, ${ }^{1,2}$ Christopher D. Connors, ${ }^{2}$ and David W. Houseknecht ${ }^{1}$
}

\section{Abstract}

The Jurassic-Lower Cretaceous Kingak Shale in the National Petroleum Reserve in Alaska (NPRA) includes several southward-offlapping depositional sequences that culminate in an ultimate shelf margin, which preserves the depositional profile in southern NPRA. The Kingak Shale thins abruptly southward across the ultimate shelf margin and grades into condensed shale, which is intercalated with underlying condensed shale and chert of the Upper Triassic Shublik Formation and overlying condensed shale of the Lower Cretaceous pebble shale unit and the gamma-ray zone (GRZ) of the Hue Shale. This composite of condensed shale forms a thin $(\approx 300$-meter) and mechanically weak section between much thicker and mechanically stronger units, including the Sadlerochit and Lisburne Groups below and the sandstone-prone foredeep wedge of the Torok Formation above.

Seismic interpretation indicates that the composite condensed section acted as the major detachment during an Early Tertiary phase of deformation in the northern foothills of the Brooks Range and that thrust faults step up northward to the top of the Kingak, or to other surfaces within the Kingak or the overlying Torok. The main structural style is imbricate fault-bend folding, although fault-propagation folding is evident locally, and large-displacement thrust faults incorporate backthrusting to form structural wedges. The Kingak ultimate shelf margin served as a ramp to localize several thrust faults, and the spatial relationship between the ultimate shelf margin and thrust vergence is inferred to have controlled many structures in southern NPRA. For example, the obliqueness of the Carbon Creek anticline relative to other structures in the foothills is the result of northward-verging thrust faults impinging obliquely on the Kingak ultimate shelf margin in southwestern NPRA.
${ }^{1}$ U.S. Geological Survey.

${ }^{2}$ Geology Department, Washington and Lee University, Lexington, Virginia.

\section{Introduction}

The architecture and geometry of clastic depositional sequences exert a primary control on the character and distribution of lithofacies and, therefore, on mechanical anisotropy. Thus, depositional sequences comprising a variety of lithofacies have the potential to significantly influence structures generated during contractional deformation. Although the effects of mechanical anisotropy arising from lithologic contrasts between formations are recognized routinely at the regional scale (for example, Wallace and Hanks, 1990), the influence of sequence stratigraphy and the inherent three-dimensional complexity in lithofacies distribution rarely are considered in studies of structural geology.

This study, based mostly on two-dimensional seismic data and sparse well control, integrates sequence stratigraphic and structural interpretations to evaluate the influence of Jurassic-Lower Cretaceous depositional sequences on the character and geometry of contractional faults and folds in the northern foothills of the Brooks Range in northern Alaska. This study was conducted in the southwestern part of the National Petroleum Reserve in Alaska (NPRA), where two main stages of contractional deformation, one in the Early Cretaceous and one in the Early Tertiary, have been documented (Moore and others, 2004).

Specific objectives of this study are to (1) document the stratal geometry of the Jurassic-Lower Cretaceous Kingak Shale, (2) interpret the geometry and kinematic origin of faults and folds, and (3) evaluate whether depositional sequences and stratal geometry influenced the development and geometry of structures. 


\section{Geologic Setting}

\section{Stratigraphy}

The stratigraphy of northern Alaska typically is divided into four tectonostratigraphic sequences that reflect main stages of tectonic development (fig. 1; Lerand, 1973; Hubbard and others, 1987). Acoustic basement consists mostly of preMississippian low-rank metamorphic rocks of the Franklinian sequence, which was broadly deformed during the Ellesmerian orogeny (Late Devonian-Early Mississippian; Moore and others, 1994). The overlying Ellesmerian sequence comprises Mississippian to Triassic marine carbonate and nonmarine to shallow-marine siliciclastic strata deposited on a south-facing (present coordinates) passive continental margin prior to opening of the Canada Basin (Bird and Houseknecht, 2011). The Beaufortian sequence is a succession of Jurassic to Lower Cretaceous (Neocomian) siliciclastic strata that record erosional and depositional effects of rift opening of the Canada Basin (Hubbard and others, 1987; Houseknecht and Bird, 2004, 2011). The Brookian sequence consists of Cretaceous to Cenozoic siliciclastic sediments derived from the Chukotka and Brooks Range orogenic belts and deposited as deep marine through nonmarine strata in the Colville foreland basin and on the continental margin to the north (Houseknecht, Bird, and Schenk, 2009; Houseknecht and Bird, 2011). Regional aspects of these four sequences have been summarized by Moore and others (1994), Bird (2001), and Bird and Houseknecht (2011).

This study is focused on a stratigraphic interval that spans from the Shublik Formation of the Ellesmerian sequence to the Nanushuk Formation of the Brookian sequence (figs. 1,2). Additional details of this stratigraphic succession are provided in the following sections.

\section{Shublik Formation}

The Middle-Upper Triassic Shublik Formation was deposited on a south-facing (present coordinates) open-marine shelf influenced by upwelling conditions (Kelly and others, 2007). The formation comprises bioclastic carbonate, siltstone, shale, and sandstone that are variably phosphatic and glauconitic. In the study area, the Shublik likely is less than 150 meters $(\mathrm{m})$ thick and comprises mostly organic rich shale and limestone (Kelly and others, 2007), although no well penetrations exist to confirm these inferences. In exposures in the eastern Brooks Range and in well penetrations to the north, the Shublik commonly is organic rich and is considered a major petroleum source rock in Arctic Alaska (Peters and others, 2006; Kelly and others, 2007).

\section{Kingak Shale}

The Jurassic-Lower Cretaceous (Neocomian) Kingak Shale in NPRA comprises a succession of southward-offlapping depositional sequences that are inferred to reflect various phases of rift-shoulder uplift and quiescence during opening of the Canada Basin (Hubbard and others, 1987; Houseknecht and Bird, 2004). An isopach map of the Kingak Shale illustrates a zone of maximum thickness (900 to more than 1,200 $m$ ) that bisects NPRA from west-northwest to east-southeast (Houseknecht and Bird, 2004). From this zone of maximum thickness, the Kingak thins gradually northward owing to depositional onlap, truncation by intraformational unconformities, and truncation by the Lower Cretaceous unconformity (LCU), which forms the upper contact of the formation (fig. 2). Southward from the zone of maximum thickness, the Kingak thins more abruptly across an ultimate shelf margin (the farthest basinward shelf margin, which preserves a relict depositional profile), and the upper contact of the formation is a correlative conformity to the LCU (Houseknecht and Bird, 2004).

Internally, the Kingak Shale comprises four depositional sequence sets, each of which is a heterolithic succession of shale, silty shale, and sandstone stacked into multiple coarsening-upward sequences. The distal part of each sequence set includes a transgressive deposit of condensed shale at the base, and the same is true of the smaller-scale sequences within each sequence set (Houseknecht and Bird, 2004). At the distal toe of each sequence set and sequence, the condensed shale downlaps to near the base of the formation and coalesces with other beds of condensed shale to form a composite condensed section in the most basinward part of the formation (fig. 2).

\section{Pebble Shale Unit and Gamma-Ray Zone}

The Kingak Shale is overlain by the mostly Hauterivian pebble shale unit (PSU), a universally applied yet informal stratigraphic term for a generally fining-upward succession of condensed shale containing variable amounts of disseminated silt, sand, pebbles, and cobbles (Bird and Molenaar, 1987; Macquaker and Keller, 2005). The PSU grades upward into the gamma-ray zone (GRZ; also called "highly radioactive zone," or HRZ), formally part of the Hue Shale (Bird and Molenaar, 1987; Mull and others, 2003). The GRZ is condensed, organic shale whose age in NPRA likely spans Barremian to Aptian. Tongues of the GRZ are draped on transgressive surfaces in the overlying Torok Formation, both in the "foredeep wedge" and foreset seismic facies of Houseknecht and Schenk (2001) and Houseknecht and others (2009b).

The PSU and basal GRZ are interpreted as a transgressive systems tract, and the remainder of the GRZ is interpreted as distal, starved basin deposits that accumulated during numerous cycles of relative sea-level change (Houseknecht, LePain, and others, 2009). Together, the PSU and GRZ comprise condensed, organic shale. Both the seismic velocity and the density of this shale are low and therefore contrast with vertically adjacent strata to yield a regionally extensive, highamplitude reflection marking the contact between Beaufortian and Brookian strata. The composite PSU-GRZ condensed shale mantles the ultimate shelf margin of the Kingak Shale and is inferred to downlap nearly onto the Kingak condensed shale in the southern part of the basin (fig. 2). 


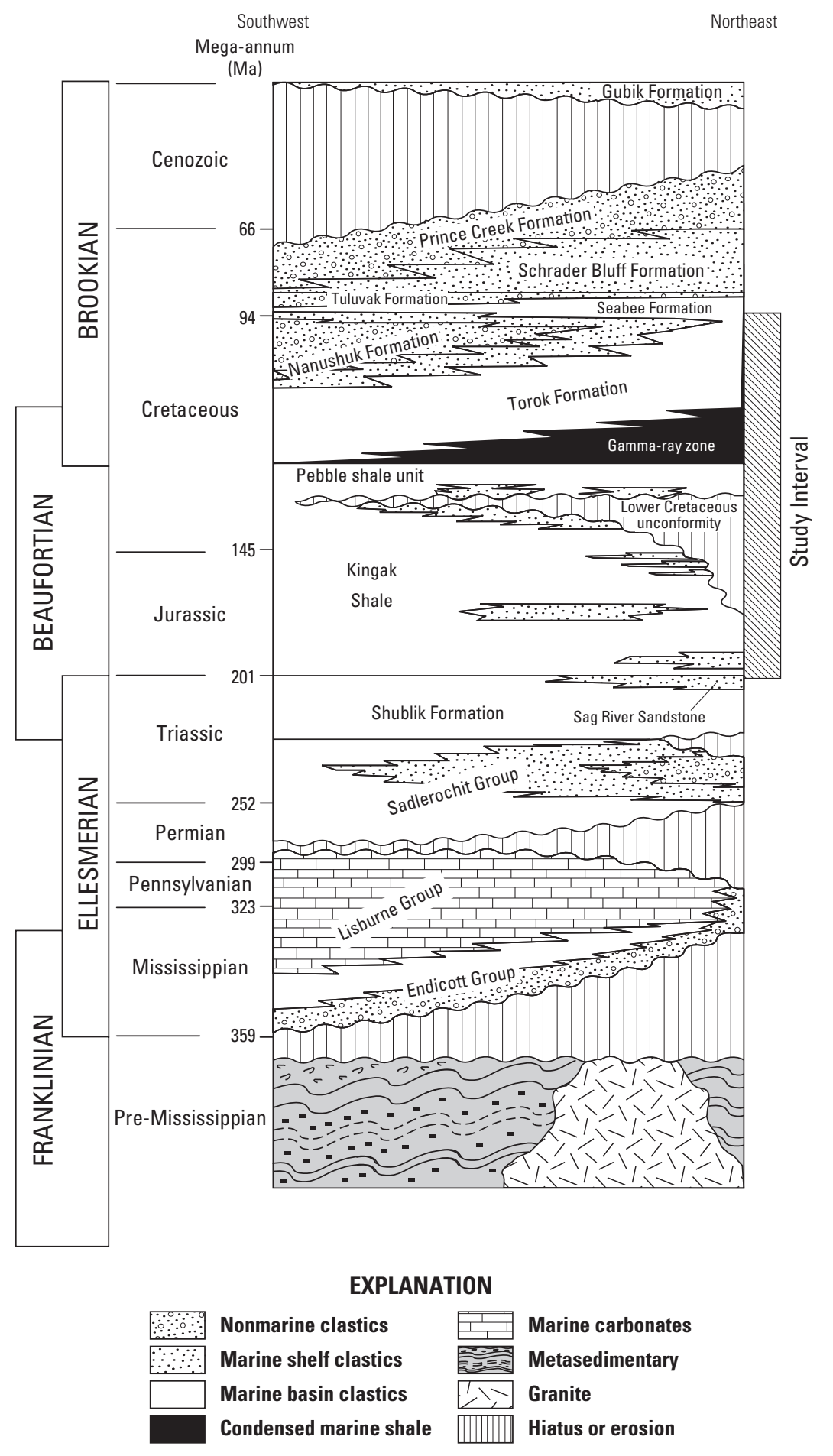

Figure 1. Chronostratigraphy of the National Petroleum Reserve in Alaska showing tectonostratigraphic sequences (modified from Houseknecht and Bird, 2004). Fm., formation; Ma, mega-annum; Ss., sandstone. 


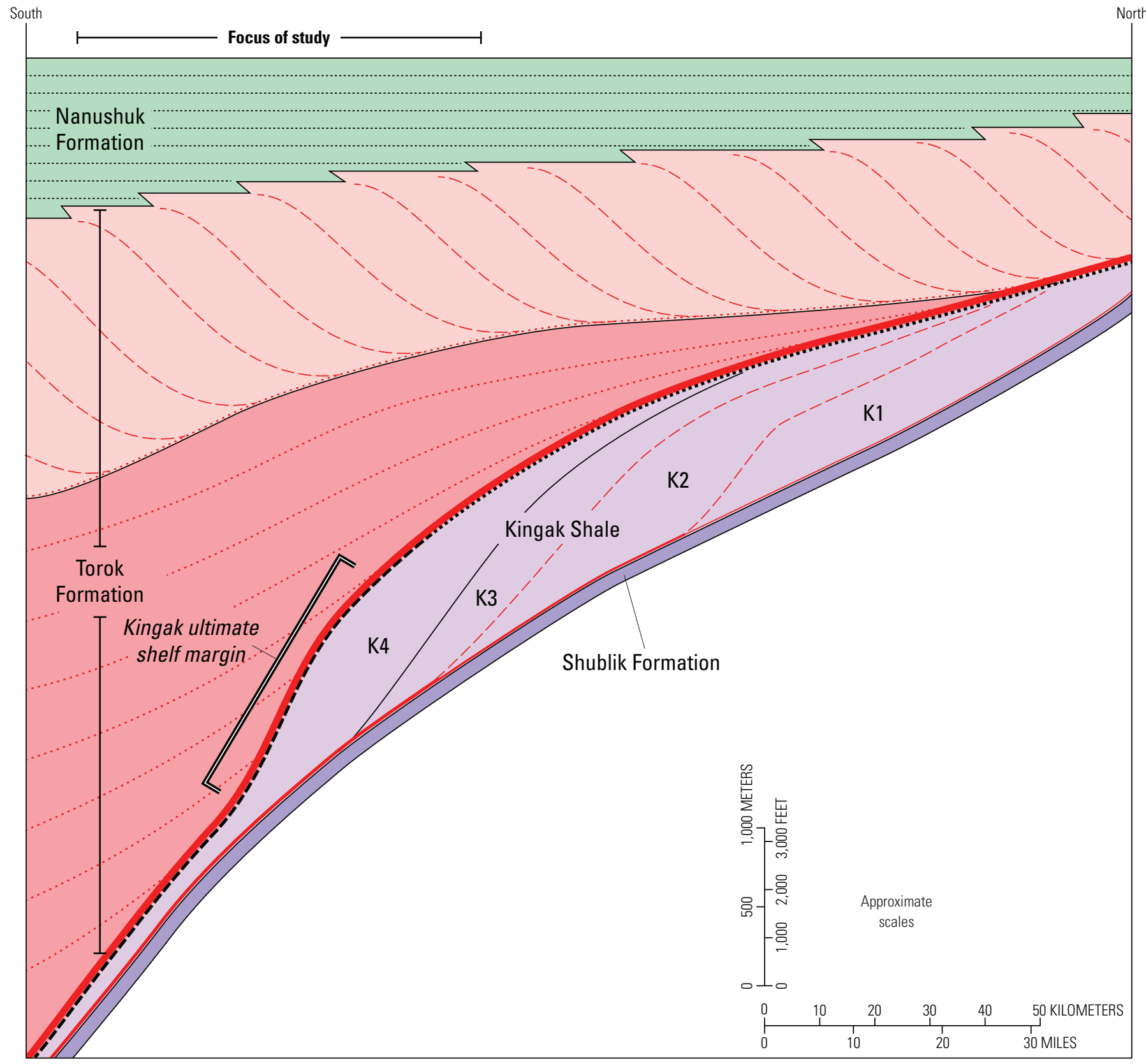

\section{EXPLANATION}

Brookian clinothem architectural elements

Nanushuk topset

Torok slope clinoform

Torok foredeep wedge

Lower Cretaceous unconformity (LCU)

Correlative conformity to LCU
Condensed shale bed

Pebble shale unit (PSU) and gammaray zone (GRZ)

ב Lower Kingak transgressive facies; reduction in line weight shows changes in rock-unit thickness. Thickness not to scale

Transgressive and highstand facies in Torok foredeep wedge

Figure 2. Architectural elements of the Shublik through Nanushuk Formations showing the opposing wedges formed by deposition of the Torok Formation on the south-facing, relict shelf-margin geometry of the Kingak Shale. The Torok foredeep wedge typically is considered "lower Torok," and the Torok slope clinoform typically is considered "upper Torok." 


\section{Torok and Nanushuk Formations}

The Torok and Nanushuk Formations, together with the GRZ, constitute a clinothem formed by a depositional system that prograded eastward and northward in the Colville foreland basin (Molenaar, 1988; Houseknecht, Bird, and Schenk, 2009). The Torok Formation, mostly Aptian-Albian in NPRA, comprises sandstone and silty mudstone deposited in basin-floor fan and marine slope environments. The Nanushuk Formation, mostly Albian-Cenomanian in NPRA, comprises mudstone, sandstone, and coal deposited in marine shelf, shoreface, delta, fluvial, and paludal coastal plain settings.

The Brookian clinothem comprises three main architectural elements in the study area (shown in figs. 3 and 4), which is on the northern margin of the Colville foredeep. The lowest element (lower part of Torok Formation) is a wedge-shaped body of mostly sandstone deposited in a basin-floor fan setting and restricted to the foredeep (fig. 2; Houseknecht and Schenk, 2001; Houseknecht, Bird, and Schenk, 2009; Houseknecht, LePain, and others, 2009). This "foredeep wedge" is at least 2 kilometers $(\mathrm{km})$ thick in the area of greatest accommodation, which is basinward of the Kingak ultimate shelf margin (fig. 2 ); it thins northward and pinches out into the GRZ. The most abrupt northward thinning occurs where the foredeep wedge pinches out across the relict Kingak ultimate shelf margin (fig. 2). The thinner, upper portion of the foredeep wedge thins more gradually northward from the Kingak ultimate shelf margin and pinches out completely across central NPRA; this architectural element is absent in northern NPRA (Houseknecht and Schenk, 2001; Houseknecht and others, 2009b). The foredeep wedge internally consists of tabular bodies of mostly sandstone tens to hundreds of meters thick and tens of kilometers wide, separated by beds of condensed shale that are tongues of the GRZ (fig. 2).

The middle architectural element (upper part of Torok Formation) is a regionally persistent, 1.0 - to $1.5-\mathrm{km}$-thick unit of silty mudstone deposited in a marine slope setting (fig. 2). Beds in this "slope clinoform" element downlap onto the foredeep wedge in the study area, downlap into the GRZ in northern NPRA where the foredeep wedge is absent, and toplap the upper architectural element (Nanushuk Formation) everywhere in NPRA. The Nanushuk Formation is the topset portion of the clinothem (fig. 2) and consists of interbedded mudstone, sandstone, and coal deposited in a spectrum of shallow marine to nonmarine environments. Although internally it appears seismically tabular, the topset element thins eastward and northward across NPRA (Bird, 1988) as the result of accommodation growth in the foredeep during deposition and the aggradational trajectory of the toplap surface that separates shallow marine facies above from marine-slope facies below (Houseknecht and Schenk, 2001; Houseknecht, Bird, and Schenk, 2009; Houseknecht, LePain, and others, 2009).

\section{Structure}

The study area lies within the Brooks Range frontal fold and thrust belt, in which structures generally grade from simple, upright folds in the north to complex folds and thrust faults involving deeper stratigraphic levels in the south (Kirschner and Rycerski, 1988; Moore and others, 1994, 2004; Potter and Moore, 2003; Duncan and others, 2012). Deformation along the northern front of the Brooks Range is inferred to have occurred in two phases: one during the Early Cretaceous and characterized by significant shortening and low structural relief, and the second during the Early Tertiary and characterized by modest shortening and significant structural relief (Moore and others, 2004). Deformation in the study area occurred mostly during the latter phase because the depositional age of deformed Brookian strata postdates the Early Cretaceous phase of tectonism and no growth strata are evident.

An apparent structural discontinuity crosses obliquely the fold and thrust belt in southwestern NPRA (Kirschner and Rycerski, 1988). Named the "Carbon Creek fault(?) zone" (fig. 3 ), the WNW.-ESE.-trending discontinuity was defined on the basis of the westward termination of W.-E. striking anticlines on the north side, a bend in the strike of the Carbon anticline (later mapped as the Carbon Creek anticline on the basis of surface geology by Mull and others (2006b)) on the south side (from W.-E. to WNW.-ESE., parallel to the discontinuity), and an abrupt southward increase in the complexity of detachment folds across the discontinuity inferred from seismic data (Kirschner and Rycerski, 1988). The discontinuity also is evident in digital elevation and Landsat images, with topography mostly controlled by long-trending anticlines defined by sandstone in the Nanushuk Formation to the north and shortertrending synclines defined by sandstone in the Nanushuk Formation to the south (fig. 3). Kirschner and Rycerski (1984) suggested that the Carbon Creek fault zone may represent a dextral strike-slip fault or en echelon series of faults. Both north- and south-vergent thrust faults were described along some segments of the anticline, but no explanation was given for the abrupt change in trend of the fold near its northwestern extent (Mull and others, 2006b).

The Carbon Creek fault zone (Kirschner and Rycerski, 1988) or anticline (Mull and others, 2006b) lies on-trend to the southeast with the Tuktu escarpment, the roof of a prominent triangle zone. The Tuktu escarpment is considered an abrupt structural boundary between domains of lesser (north) and greater (south) degrees of deformation (Potter and Moore, 2003; Moore and others, 2004; Duncan and others, 2012).

\section{Methods}

This subsurface study is based mostly on two-dimensional seismic data and sparse well control, although published outcrop data were used to corroborate observations and 


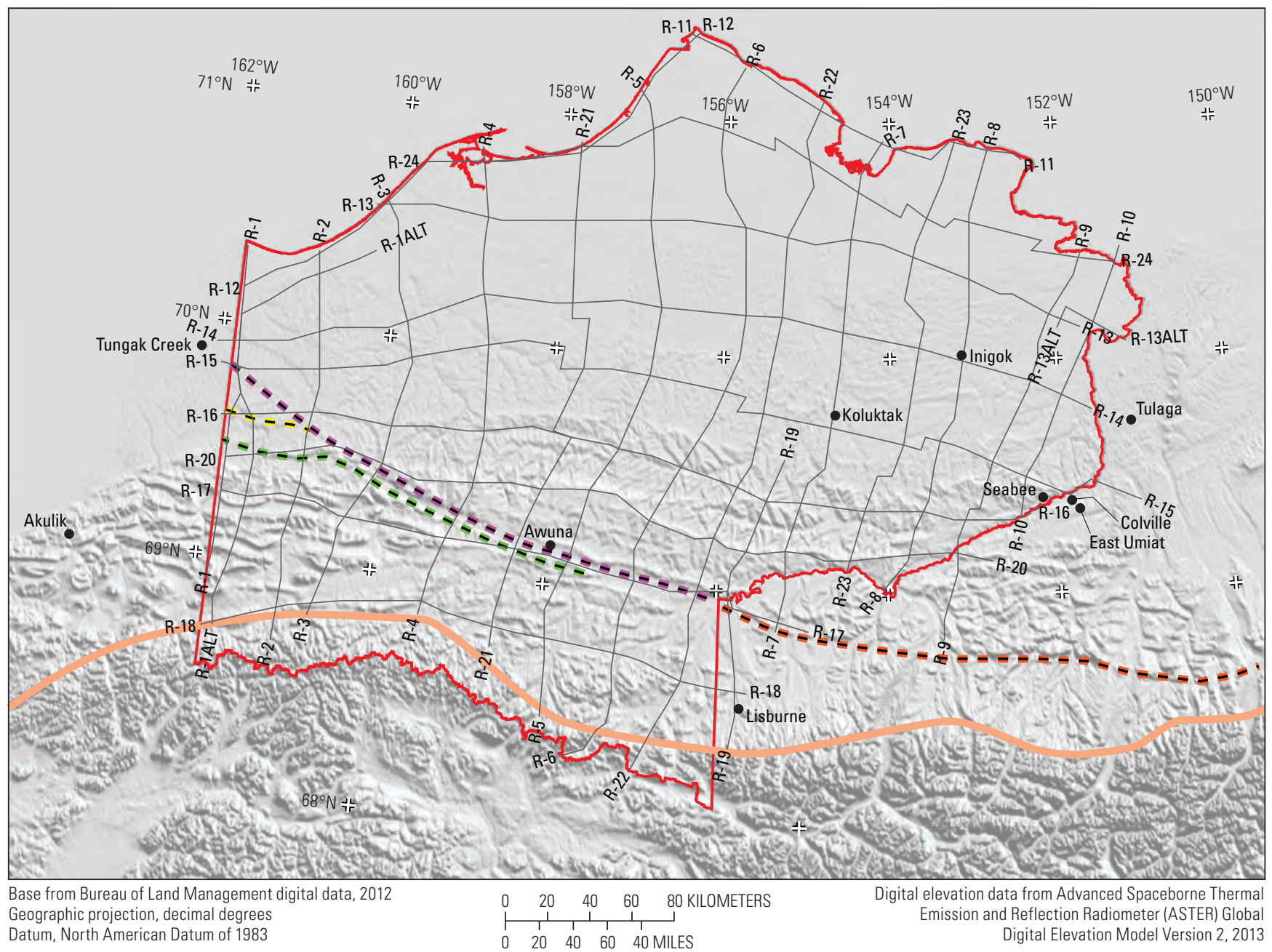

\section{EXPLANATION}
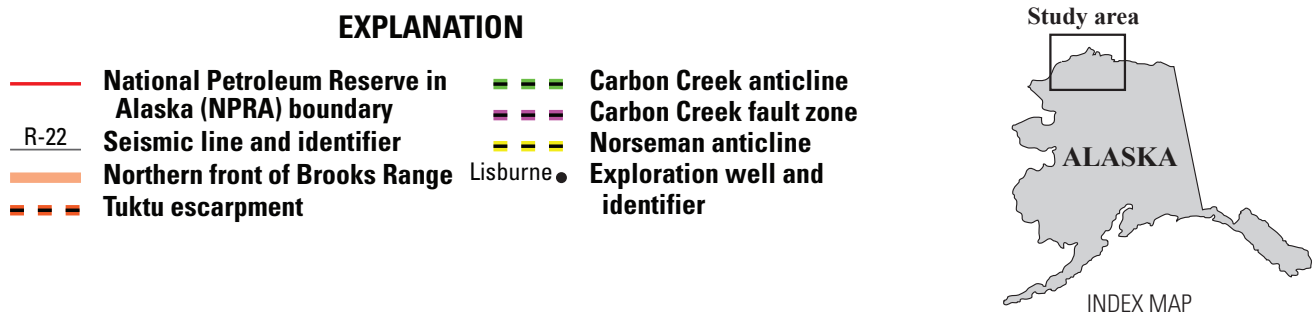

Figure 3. Digital elevation model (NASA Aster data) of the National Petroleum Reserve in Alaska (NPRA) showing regional structural features mapped at surface, exploration well locations, and USGS regional seismic lines (Miller and others, 2000, 2001). The northern front of the Brooks Range is approximated from Moore and others (1994). NPRA is outlined in red.

interpretations. Most stratigraphic and structural interpretation was done on a digital workstation running IHS Kingdom ${ }^{\circledR}$ 8.7 software. Stratigraphic and structural interpretations were performed on a regional grid of 1974-1981 vintage, publicdomain seismic data comprising 26 lines that previously had been reprocessed by using post-stack time processing techniques (Miller and others, 2000, 2001).

Formation tops and key sequence boundaries were correlated across the study area on the basis of reflection continuity and concepts of seismic/sequence stratigraphy. Sequence boundaries and other key surfaces in the Kingak Shale and
Brookian clinothem were based on interpretations of Houseknecht and Bird (2004), Houseknecht, Bird, and Schenk (2009), and Houseknecht, LePain, and others (2009) and correlated into areas not previously mapped on the basis of continuity of seismic reflections. Faults and folds were interpreted on seismic lines by using the principles of fault-related folding outlined by Shaw and others (2005).

Formation tops and other key stratigraphic surfaces, most of which were picked in wireline logs from exploration wells by Kenneth J. Bird (USGS, retired), were tied to nearby seismic lines to establish an initial time-depth (T-D) function for 
each well. The initial well ties were based on the interpretations of previous workers (for example, Molenaar, 1988; Bird and Molenaar, 1992; Houseknecht and Bird, 2004; Kulander and others, 2005; Houseknecht, Bird, and Schenk, 2009) and correlation between distinct seismic reflections and well-log response. These well ties subsequently were refined by construction of a synthetic seismogram for each well for which both sonic and density logs were available, as well as by correlation of the resultant synthetic to nearby seismic lines.

\section{Observations and Interpretations}

\section{Stratal Geometry}

The overall geometry of the Kingak Shale was confirmed by constructing an isochron map (fig. 4) between the top of the Shublik Formation (or top of the Sag River Sandstone in northern NPRA) and the top of the Kingak Shale (fig. 1). A zone of maximum thickness, defined approximately by the 0.5 -second isochron, bisects NPRA from west-northwest to east-southeast. Using a time-thickness function $(0.18$ second equals approximately $300 \mathrm{~m}$ ) for the Kingak Shale, derived from the T-D function calculated for the Husky Inigok \#1 well ("Inigok" in fig. 3), we estimate that the zone of maximum thickness ranges from about $750 \mathrm{~m}$ to about 1,200 m. Northward from the zone of maximum thickness, the Kingak Shale thins gradually to a featheredge or complete pinchout near the northeastern boundary of NPRA (fig. 4). Southward from the zone of maximum thickness, the Kingak Shale thins more abruptly to about $150 \mathrm{~m}$ (less than 0.1 second; fig. 4).

Our isochron map is consistent - both in overall geometry and absolute thickness - with a previously published isopach map constructed using depth-converted seismic data and well penetrations (fig. 1 of Houseknecht and Bird, 2004). The isochron map extends farther south and therefore better defines the basinward thinning across the relict Kingak ultimate shelf margin. This relict shelf margin preserves between 600 and $1,050 \mathrm{~m}$ of relief over a distance of 15 to $40 \mathrm{~km}$. The southward thinning also corresponds to the gradation of the Kingak Shale into a basinal condensed section. Significantly, the relict Kingak shelf edge, defined approximately by the 0.5 -second isochron along the southern margin of the zone of maximum thickness, is not linear across the width of NPRA but displays a prominent southward bulge in southwest-central NPRA (fig. 4).

Although deformation precludes detailed estimation of the thickness of the Torok foredeep wedge, it thickens southward from a few hundred meters in central NPRA to more than 3,000 $\mathrm{m}$ in southern NPRA. The southward thickening is attributed partly to the $600-1,050 \mathrm{~m}$ of increased accommodation across the relict Kingak shelf margin and partly to flexural subsidence of the Colville foredeep in response to tectonic loading of the Early Cretaceous ancestral Brooks Range. Our seismic observations indicate that the most abrupt thickening of the Torok foredeep wedge occurs across the relict Kingak shelf margin, as depicted in figure 2 .

The thickness of neither the Torok slope clinoform nor the Nanushuk topset architectural element appears to be influenced by the relict Kingak shelf margin. The southward thickening displayed by both occurs on a broader scale that we interpret to be the result of flexural subsidence of the foredeep.

\section{Structural Deformation}

The structural style of the study area primarily involves south-dipping thrust faults and fault-related folds (pl. 1; available for download at http://pubs.usgs.gov/sir/2014/5056/). North-vergent thrust faults commonly tip out and link with north-dipping back thrusts. Together, the thrusts and back thrusts form structural wedges that accommodate a large amount of slip. Deformation decreases in complexity and steps to higher (younger) stratigraphic horizons northward, an observation that is consistent with the work of others (for example, Kirschner and Rycerski, 1988; Potter and Moore, 2003; Moore and others, 2004; Duncan and others, 2012).

In the southern part of the study area, most thrust faults step up from a detachment in a thin $(\approx 300-m)$ stratigraphic succession that includes the Shublik Formation, Kingak Shale, PSU, and GRZ. All these formations in this part of the basin are thin and comprise mainly condensed and organic rich shale. Although we are not aware of any mechanical data for these formations, experimental data for similar shale demonstrate that they are uniformly weak compared to other lithologies (Goodman, 1989). We infer, therefore, that the Shublik, Kingak, PSU, and GRZ in the study area form a composite, mechanically weak interval intercalated between thicker and mechanically more competent strata of the Sadlerochit, Lisburne, and Endicott Groups below (fig. 1) and the foredeep wedge of the Torok Formation above (fig. 2).

To the north, the thrust faults ramp up and detach again within the Kingak, at the top of the Kingak, or in the Torok foredeep wedge. Our observations suggest that the locations of ramps and detachments commonly are influenced by the presence of mechanically weak shale beds whose character and distribution are related to sequence stratigraphy. Specifically, shale beds in the Kingak and Torok occur as transgressive deposits above flooding surfaces, which typically are localized above lowstand sequence boundaries (Houseknecht and Bird, 2004; Houseknecht, Bird, and Schenk, 2009). In the western and eastern parts of our study area, most thrust faults with significant throw (>300 $\mathrm{m}$ ) ramp up through the lower part of the Torok foredeep wedge and detach along one of the condensed shale tongues of the GRZ (pl. 1, lines R-3, R-6, and R-22). These locations lie basinward of the Kingak relict shelf margin, in places where the Kingak comprises a thin, condensed shale.

In the central part of our study area, where strata deformed during the Tertiary phase of Brookian tectonism intersect the southward bulge in the Kingak relict shelf 


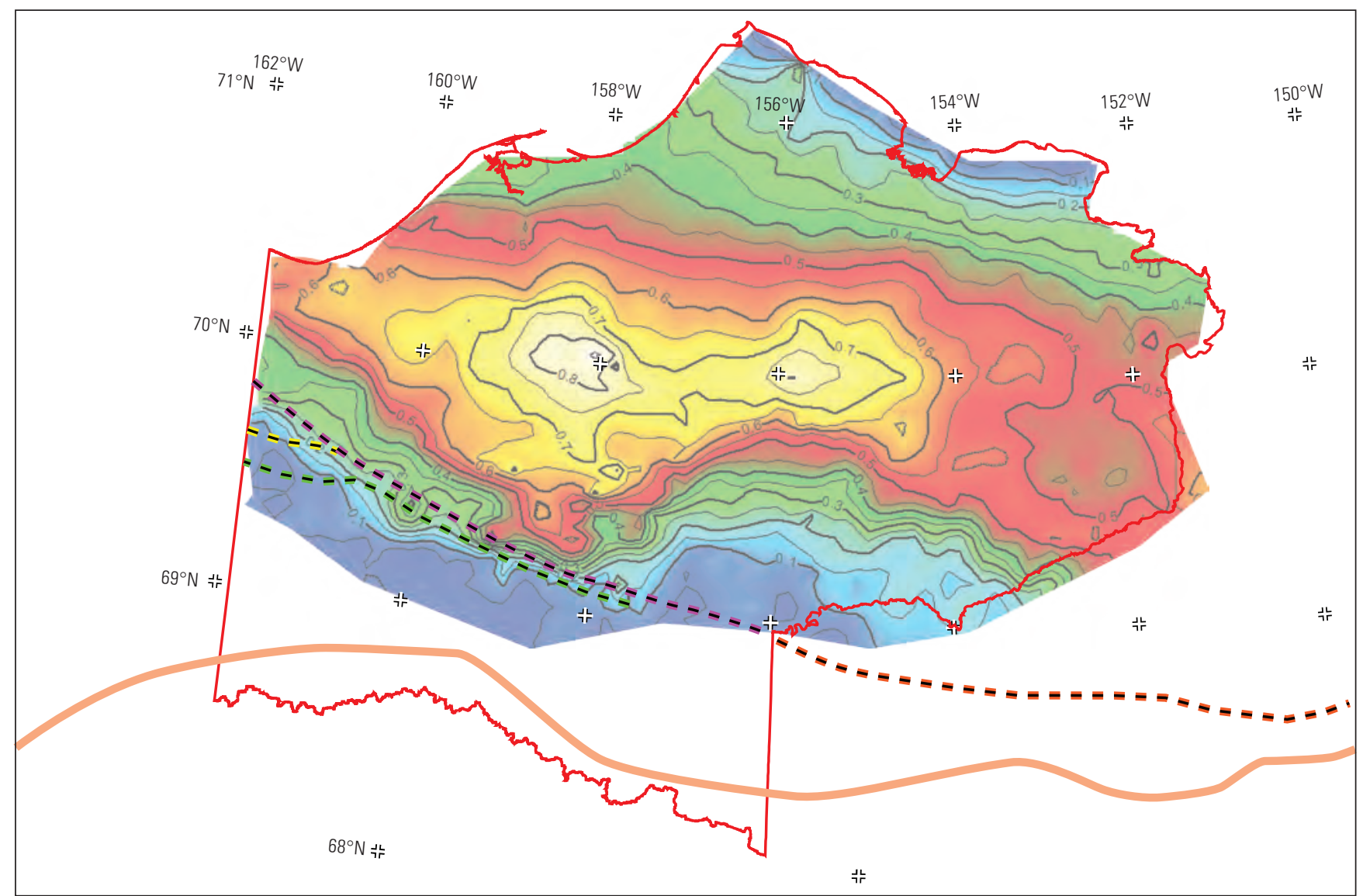

Base from Bureau of Land Management digital data, 2012

Geographic projection, decimal degrees

Datum, North American Datum of 1983

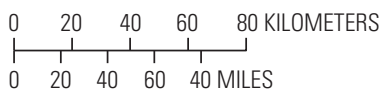

$0 \quad 20 \quad 40 \quad 60 \quad 40$ MILES

\section{EXPLANATION}

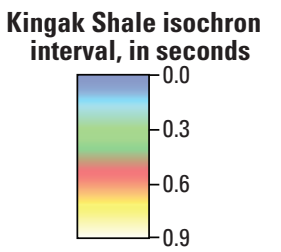

$=E$ Carbon Creek anticline

$=$ = Carbon Creek fault zone

- - Norseman anticline

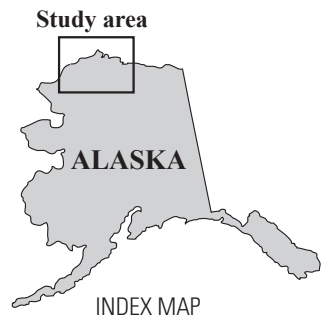

Figure 4. Isochron map of the stratigraphic interval between the top of the Kingak Shale and the top of the Shublik Formation. Study was limited to polygon that defines outer boundaries of isochron map.

margin, thrust faults with significant throw detach in or near the PSU-GRZ where the composite condensed section is draped on the south-dipping relict shelf margin (pl. 1, lines $\mathrm{R}-4, \mathrm{R}-21$, and R-5). Some of these detachments ramp directly up from the relict shelf margin into the Torok foredeep wedge and then detach again along a tongue of the GRZ. Others continue northward from the relict shelf edge for several kilometers in the composite condensed section at the top of the Kingak and then either ramp up into the Torok foredeep wedge or tip out in or near the PSU-GRZ condensed section.

Most folds observed in the study area are fault-bend folds consistent with the relationships as described by Shaw and others (2005). Imbricated break-forward fault-bend folds occur in certain areas, including locations where the Kingak relict shelf margin is interpreted to have localized increased shortening (pl. 1, line R-4). Some of the faults involved with the imbricated fault-bend folding appear to break through to the surface, an observation corroborated by the coincidence of thrust faults shown on published geologic and structure maps (Mayfield and others, 1988; Kirschner and Rycerski, 1988; Mull and others, 2005, 2006a, 2006b). The main imbricate system concentrated above the Kingak relict shelf margin displays a total slip of about $6 \mathrm{~km}$. 


\section{Discussion}

The geometry of the fold and thrust belt in southwestern NPRA appears generally parallel to the prominent northward bulge in the Brooks Range front (fig. 3). The range front trends west-southwest to east-northeast from the western NPRA boundary $\left(161.8^{\circ} \mathrm{W}\right.$.) to about $159^{\circ} \mathrm{W}$., from where it trends southeastward to about $157.5^{\circ} \mathrm{W}$. Most surface folds in southwestern NPRA are broadly parallel to the range front, as illustrated by their topographic expression (fig. 3). In contrast, the Carbon Creek anticline is divergent from this general pattern, trending southeast-northwest from about $157^{\circ} \mathrm{W}$ to about $161^{\circ} \mathrm{W}$., from where it trends westward to the NPRA boundary (fig. 3). The change in trend of the Carbon Creek anticline, together with other subtle evidence, led Kirschner and Rycerski (1988) to speculate the presence of the right-lateral Carbon Creek fault zone (fig. 3). However, our observations of the subsurface structure do not reveal compelling evidence for strike-slip faulting near the Carbon Creek anticline. We do note a zone of imbricated thrusts along the trend of the Carbon Creek anticline and continuing to the northwest beyond the Norseman anticline (fig. 3; Kirschner and Rycerski, 1988; Mull and others, 2006b). Thus this imbricate zone in southwestern NPRA is oblique to the main structural grain.

We propose that the northwest-southeast trending Carbon Creek anticline and associated oblique structures (Norseman anticline and others) are an imbricate of repeated Kingak through Torok Formations. These structures are oblique to other structures in southwestern NPRA because the Kingak shelf margin, which controlled the depth of the basal detachment, happens to be oblique to the strike of the Brooks Range in this area (fig. 4; pl. 1). The Kingak shelf margin strikes northwest-southeast, and the Brooks Range trends west-east. The seismic lines in plate 1 show that the imbricated faultbend folding south of Kingak shelf margin is associated with a deeper detachment. To the north, imbrication is less significant and detaches within the Torok. Figures 3 and 4 together show how the strike of the Brooks Range differs from the strike of the Kingak shelf margin in western NPRA.

Structural features near the southeastern part of the Carbon Creek fault zone are not oblique to the strike of the Brooks Range. They both trend southeast-northwest (pl. 1, fig. 3). In southeastern NPRA the major imbricated fault-bend folds do not occur at the Kingak shelf margin as they do to the west, although thrusting is associated with the Kingak margin. We infer that this localization of thrusting occurs because the Kingak margin comprises a southward-thinning stratal geometry draped by mechanically weak shale, an effective combination for thrust ramp localization (pl. 1). However, the major structural break in this part of NPRA is south of the Kingak margin where the Carbon Creek anticline has been mapped (pl. 1, fig. 3, fig. 4). This imbricate system of focused contraction appears to extend eastward to the Tuktu triangle zone (Potter and Moore, 2003; Moore and others, 2004; Duncan and others, 2012).

\section{Conclusions}

Regional sequence stratigraphy of the Jurassic to Lower Cretaceous Kingak Shale in southern NPRA controlled mechanical stratigraphy, which in turn influenced the structures generated during the early Tertiary phase of Brookian folding and thrust faulting. The major detachment is the basal condensed section, which comprises the Shublik Formation, Kingak Shale, the pebble shale unit and the gamma-ray zone (fig. 1, fig. 2, pl. 1). Thrust faults step up from this detachment to the top of the Kingak, to another depositional sequence within the Kingak Formation, or to a sequence boundary within the Torok Formation.

The structural style is imbricate fault-bend folding. There is some fault-propagation folding, and thrusts with large amounts of displacement locally incorporate backthrusting to form a structural wedge or triangle zone in order to accommodate large amounts of slip. These major imbricate systems and other smaller thrusts make use of the Kingak ultimate shelf margin, which is an effective surface on which thrusts can ramp. The obliqueness of the Carbon Creek anticline relative to other structures in the foothills is the result of northwardverging thrust faults impinging obliquely on the Kingak ultimate shelf margin, which is oriented northwest-southeast in southwestern NPRA.

\section{References}

Bird, K.J., 1988, Structure-contour and isopach maps of the National Petroleum Reserve in Alaska, in Gryc, George, ed., Geology and exploration of the National Petroleum Reserve in Alaska, 1974 to 1982: U.S. Geological Survey Professional Paper 1399, p. 355-377.

Bird, K.J., 2001, Alaska-A twenty-first-century petroleum province, in M.W. Downey, Threet, J.C., and Morgan, W.A., eds., Petroleum provinces of the twenty-first century: American Association of Petroleum Geologists Memoir 74, p. $137-165$.

Bird, K.J., and Houseknecht, D.W., 2011, Geology and petroleum potential of Arctic Alaska, in Spencer, A.M, Embry, A.F., Gautier, D.L., Stoupakova, A.V., and Sørensen, K., eds., Arctic petroleum geology: Geological Society of London Memoir 35, p. 485-499.

Bird, K.J., and Molenaar, C.M., 1987, Stratigraphy, in Bird, K.J., and Magoon, L.B., eds., Petroleum geology of the northern part of the Arctic National Wildlife Refuge, northeastern Alaska: U.S. Geological Survey Bulletin 1778, p. $37-59$. 
Bird, K.J., and Molenaar, C.M., 1992, The North Slope foreland basin, Alaska, in Macqueen, R.W., and Leckie, D.A., eds., Foreland basins and foldbelts: American Association of Petroleum Geologists Memoir 55, p. 363-393.

Duncan, Alec; Hanks, Catherine; Wallace, W.K.; O’Sullivan, P.B.; and Parris, T.M., 2012, An integrated model for the structural evolution of the Brooks Range foothills, Alaska, using structural geometry, fracture distribution, geochronology, and microthermometry: American Association of Petroleum Geologists Bulletin, v. 96, no. 12, p. 2245-2274.

Goodman, R.E., 1989, Introduction to rock mechanics (2d ed.): New York, Wiley, 562 p.

Houseknecht, D.W., and Bird, K.J., 2004, Sequence stratigraphy of the Kingak Shale (Jurassic-Lower Cretaceous), National Petroleum Reserve in Alaska: American Association of Petroleum Geologists Bulletin, v. 88, p. 279-302.

Houseknecht, D.W., and Bird, K.J., 2011, Geology and petroleum potential of the rifted margins of the Canada basin, in Spencer, A.M, Embry, A.F., Gautier, D.L., Stoupakova, A.V., and Sørensen, K., eds., Arctic petroleum geology: Geological Society of London Memoir 35, p. 509-526.

Houseknecht, D.W., and Schenk, C.J., 2001, Depositional sequences and facies in the Torok Formation, National Petroleum Reserve-Alaska (NPRA), in Houseknecht, D.W., ed., 2001, NPRA Core Workshop-Petroleum Plays and Systems in the National Petroleum Reserve-Alaska: Society of Economic Paleontologists and Mineralogists Core Workshop 21, p. 179-199.

Houseknecht, D.W., Bird, K.J., and Schenk, C.J., 2009, Seismic analysis of clinoform depositional sequences and shelfmargin trajectories in Lower Cretaceous (Albian) strata, Alaska North Slope: Basin Research, v. 21, p. 644-654.

Houseknecht, D.W., LePain, D.L., Decker, P.L., and Schenk, C.J., 2009, Lower Cretaceous clinoforms in Arctic AlaskaCore workshop: American Association of Petroleum Geologists and Alaska Geological Society, Core Workshop Notes from 2009 AAPG Annual Meeting, Denver, Colo., 91 p.

Hubbard, R.J., Edrich, S.P., and Rattey, R.P., 1987, Geologic evolution and hydrocarbon habitat of the "Arctic Alaska microplate": Marine and Petroleum Geology, v. 4, no. 1, p. 2-34.

Kelly, L.N., Whalen, M.T., McRoberts, C.A., Hopkin, E., and Tomsich, C.S., 2007, Sequence stratigraphy and geochemistry of the upper Lower through Upper Triassic of northern Alaska-Implications for paleoredox history, source rock accumulation, and paleoceanography: Alaska Geological and Geophysical Surveys Report of Investigations 2007-1, 50 p., accessed June 26, 2013, at http://www.dggs.alaska. gov/pubs/id/15773.
Kirschner, C.E., and Rycerski, B.A., 1988, Petroleum potential of representative stratigraphic and structural elements, in Gryc, George, ed., Geology and exploration of the National Petroleum Reserve in Alaska, 1974 to 1982: U.S. Geological Survey Professional Paper 1399, p. 191-208.

Kulander, C.S., Grow, J.A., Potter, C.J., Saltus, R.W., and Killgore, M.L., 2005, Interpreted regional seismic reflection lines, National Petroleum Reserve Alaska: U.S. Geological Survey Open-File Report 2005-1402, 21 p., accessed June 26, 2013, at http://pubs.usgs.gov/of/2005/1402/.

Lerand, M., 1973, Beaufort Sea, in McCrossan, R.G., ed., The future petroleum provinces of Canada-Their geology and potential: Canadian Society of Petroleum Geology Memoir 1, p. 315-386.

Maquaker, J.H.S., and Keller, M.A., 2005, Mudstone sedimentation at high latitudes - Ice as a transport medium for mud and supplier of nutrients: Journal of Sedimentary Research, v. 75, no. 4, p. 696-709, doi:10.2110/jsr.2005.056.

Mayfield, C.F., Tailleur, I.L., and Kirschner, C.E., 1988, Bedrock geologic map of the National Petroleum Reserve in Alaska, in Gryc, George, ed., Geology and exploration of the National Petroleum Reserve in Alaska, 1974 to 1982: U.S. Geological Survey Professional Paper 1399, p. 187-190, scale 1:500,000.

Miller, J.J.; Agena, W.F.; Lee, M.W.; Zihlman, F.N.; Grow, J.A.; Taylor, D.J.; Killgore, Michele; and Oliver, H.L., 2000, Regional seismic lines reprocessed using post-stack processing techniques - National Petroleum ReserveAlaska: U.S. Geological Survey Open File Report 00-286, $13 \mathrm{p}$.

Miller, J.J.; Agena, W.F.; Lee, M.W.; Zihlman, F.N.; Grow, J.A.; Taylor, D.J.; Killgore, Michele; and Oliver, H.L., 2001, Four regional seismic lines-National Petroleum Reserve-Alaska (Supplement to U.S. Geological Survey Open File Report 00-286): U.S. Geological Survey Open File Report 01-337, 12 p.

Molenaar, C.M., 1988, Depositional history and seismic stratigraphy of Lower Cretaceous rocks in the National Petroleum Reserve in Alaska and adjacent areas, in Gryc, George, ed., Geology and exploration of the National Petroleum Reserve in Alaska, 1974 to 1982: U.S. Geological Survey Professional Paper 1399, p. 593-621.

Moore, T.E., Potter, C.J., O’Sullivan, P.B., Shelton, K.L., and Underwood, M.B., 2004, Two stages of deformation and fluid migration in the west-central Brooks Range fold-andthrust belt, northern Alaska, in Swennen, Rudy; Roure, François; and Granath, J.W., eds., Deformation, fluid flow and reservoir appraisal in foreland fold-and-thrust belts: American Association Petroleum Geologists Hedberg Series, no. 1, p. 157-186. 
Moore, T.E., Wallace, W.K., Bird, K.J., Karl, S.M., Mull, C.G., and Dillon, J.T., 1994, Geology of northern Alaska, in Plafker, George, and Berg, H.C., eds., The geology of Alaska: Boulder, Colo., Geological Society of America, The Geology of North America, v. G-1, p. 49-140.

Mull, C.G., Houseknecht, D.W., and Bird, K.J., 2003, Revised Cretaceous and Tertiary stratigraphic nomenclature in the Colville basin, northern Alaska: U.S. Geological Survey Professional Paper 1673, p. 1-26.

Mull, C.G., Houseknecht, D.W., Pessel, G.H., and Garrity, C.P., 2005, Geologic map of the Ikpikpuk River quadrangle, Alaska: U.S. Geological Survey Scientific Investigations Map 2817-B, scale 1:250,000, accessed June 26, 2013, at http://pubs.er.usgs.gov/publication/sim2817B.

Mull, C.G., Houseknecht, D.W., Pessel, G.H., and Garrity, C.P., 2006a, Geologic map of the Lookout Ridge quadrangle, Alaska: U.S. Geological Survey Scientific Investigations Map 2817-C, scale 1:250,000, accessed June 26, 2013, at http://pubs.usgs.gov/sim/2006/2817c/.

Mull, C.G., Houseknecht, D.W., Pessel, G.H., and Garrity, C.P., 2006b, Geologic map of the Utukok River quadrangle, Alaska: U.S. Geological Survey Scientific Investigations Map 2817-D, scale 1:250,000, accessed June 26, 2013, at http://pubs.usgs.gov/sim/2006/2817d/.
Peters, K.E., Magoon, L.B., Bird, K.J., Valin, Z.C., and Keller, M.A. 2006, North Slope Alaska-Source-rock distribution, richness, thermal maturity and petroleum charge: American Association of Petroleum Geologists Bulletin, v. 90, no. 2, p. 261-292.

Potter, C.J., and Moore, T.E., 2003, Brookian structural plays in the National Petroleum Reserve, Alaska: U.S. Geological Survey Open-File Report 03-266, 49 p., accessed June 26, 2013, at http://pubs.usgs.gov/of/2003/of03-266/.

Shaw, J.H., Connors, C.D., and Suppe, J., 2005, Interpretation methods, in Shaw, J.H., Connors, C.D. and Suppe, J., eds., Seismic interpretation of contractional fault-related folds: American Association of Petroleum Geologists Studies in Geology 53, p. 1-58.

Wallace, W.K., and Hanks, C.L., 1990, Structural provinces of the northeastern Brooks Range, Arctic National Wildlife Refuge, Alaska: American Association of Petroleum Geologists Bulletin, v. 74, no. 7, p. 1100-1118. 
For additional information regarding this publication, contact:

Energy Resources

U.S. Geological Survey

915-A National Center

12201 Sunrise Valley Drive

Reston, VA 20192

http://energy.usgs.gov/

Prepared by:

USGS Science Publishing Network

Raleigh and Columbus Publishing

Service Centers 



\section{这}

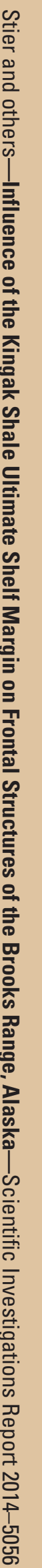

